\title{
The Relationship of Angiotensin I-Converting Enzyme Genotype to Liver Fibrogenesis in Non-Alcoholic Steatohepatitis
}

\author{
KARIMA DIAB, M.D. ${ }^{\mathbf{1}}$; HATEM RABIE, M.D. ${ }^{\mathbf{1}}$; HATEM ATTIA, M.D. ${ }^{\mathbf{1}}$; ABDEL MOATY A. ODA, M.D. ${ }^{\mathbf{2}}$; \\ AMR A. ELSHORMILISY, M.D. ${ }^{3}$; SOMIA M. MOHAMED, M.D. ${ }^{4}$; EMAN E. ELSHEMY, M.D. ${ }^{\mathbf{5}}$ and \\ NESSREN M. BAHAA EL-DEEN, M.D. ${ }^{5}$ \\ The Departments of Clinical Pathology ${ }^{1} \&$ Hepatology ${ }^{2}$, National Liver Institute, Menoufia University; Internal Medicine ${ }^{3}$, \\ Faculty of Medicine, Helwan University; Physiology ${ }^{4}$ and Hepatogastroentrology \& Infectious Diseases ${ }^{5}$, Faculty of Medicine \\ for Girls, Al-Azhar University
}

\begin{abstract}
Background: Multiple genetic and environmental factors may lead to fibrogenesis in patients with Non-alcoholic fatty liver (NAFL). Many studies investigated the relation of angiotensin I-converting enzyme (ACE) genotyping to liver fibrosis in chronic liver disease; and the results are contradictory.
\end{abstract}

Aim of Study: In the current study, ACE genotype was assessed in NAFLD patients to show its possible association with development liver fibrosis.

Subjects and Methods: The study included 162 patients of NAFLD disease, $49(30.25 \%)$ patients with mild fibrosis, $65(40.12 \%)$ with moderate fibrosis and $48(29.63 \%)$ with severe fibrosis in addition to 138 volunteers was enrolled as a healthy controls. All patients and controls were investigated to serum glucose and fasting insulin level and HOMA-IR was calculated. Liver function tests, both serum ACE and transforming growth factor-beta (TGF-b) were done. ACE genotyping [insertion/deletion (I/D)] was done by PCR.

Results: Fasting glucose and insulin, HOMA-IR, AST, ALT and GGT were significantly higher in NAFLD patients than healthy controls. The homozygous frequency I/I and D/D or D/I of ACE were not significantly different between NAFLD patients and controls. The D/D genotype was associated significantly with the severity of liver fibrosis, D/I polymorphism with moderate fibrosis and I/I genotype with mild fibrosis. The higher $\mathrm{D}$ allele frequency was associated with severe fibrosis, while I allele was frequent in mild fibrosis. The HOMA-IR, ALT, serum ACE and TGF-b were increased significantly in the patients carrying $\mathrm{D} / \mathrm{D}$ homozygous gene more than those carrying homozygous $\mathrm{I} / \mathrm{I}$ or $\mathrm{D} / \mathrm{I}$ polymorphism. The serum ACE and TGF-b were significantly higher in NAFLD patients compared to control and the most higher levels was reported in cases with severe liver fibrosis than moderate and mild liver fibrosis.

Correspondence to: Dr. Karima Diab, The Department of Clinical Pathology, National Liver Institute,

Menoufia University
Conclusion: ACE (D/D) genotype was closely associated with liver fibrosis severity and ACE (I/D) polymorphism was observed in moderate stage of fibrosis. The allele $\mathrm{D}$ is seems to be a risk factor for liver fibrosis development than allele I. The knowledge of the ACE genotypes in NAFLD patients may be important for treatment decision in those patients and beneficial in the follow-up of the disease progression.

Key Words: NAFLD - Liver fibrosis - ACE - TGF-b.

\section{Introduction}

NON-ALCOHOLIC steatohepatitis (NASH) is known as a major cause of liver fibrogenesis and it is included in a disease development from a simple steatosis (SS) to fibrosis and subsequent liver cirrhosis [1]. Many studies have evaluated the NASH pathogenesis; however it is not well understood. The first hit, is attributed to the accumulation of fat within the liver; and associated with an insulin resistance (IR) causing to hepatic steatosis. The second hit is, oxidative stress (OS) and production of abnormal inflammatory cytokines in the liver tissue play an important role in the NASH pathogenesis [2]

In chronic inflammation status, the reninangiotensin system (RAS) is involved in the pathogenesis of many diseases including fibrosis in several organs as the liver, kidney, heart and lung through the cell growth regulation, inflammation, OS and subsequent fibrosis [3]. The angiotensin II (ANG II) is a potent fibrogenesis molecule such as transforming growth factor- 31 . ANG II induce hepatic inflammation by release of cytokine and stimulate a range of fibrogenic action through extracellular matrix deposition, myofibroblast proliferation and contraction, and collagen synthesis by hepatic stellate cells (HSC) activation [4,5] 
The angiotensin I-converting enzyme (ACE-I) is the key enzyme in RAS which converts angiotensin-I to the potent vasoconstrictor angiotensinII (ANG II), which is present mainly in the most endothelial cells of body [6]. The ACE gene is composed of 26 exons and localized on chromosome $17 \mathrm{q} 23$ [7], the gene polymorphism as insertion (I) or deletion (D) of a 300 base pair in Alu repeat site localized in 16 th intron of human ACE gene. The ACE (I/D) genotype polymorphism is associated with changes in plasma level of ACE. The highest ACE plasma level is associated with the homozygous D/D genotype (deletion of a 287-base pair fragment of intron 16 of the ACE gene allele), the intermediate level with heterozygous I/D genotype, and the lowest level with heterozygous I/I of ACE polymorphism [8]

The role of the ACE gene polymorphism has been investigated as a risk factor in several diseases [9] as systemic hypertension, coronary artery disease, atherosclerosis, and diabetic nephropathy [10]. The association between ACE polymorphism and NASH pathogenesis is not yet confirmed, so this study is designed to clarify this relationship.

\section{Subjects and Methods}

The current study was conducted on 162 nonalcoholic fatty liver disease (NAFLD) patients, 97 were males and 65 were females, age range 32 to 54 years with mean \pm SD $41.3 \pm 7.6$ years. They are attending the outpatient clinic of the National Liver Institute, at the period from May 2018 till April 2019. NAFLD was diagnosed by hepatic ultrasongraphy and histopathological by liver biopsy (the degree of necro-inflammation and liver fibrosis are assessed according to the criteria of Ishak histological grading [11], the fibrosis stage were scored from 1-6, the stage from 1-2 is considered mild fibrosis and from 3-4 is of moderate fibrosis and severe fibrosis from 5-6 stage.

Exclusion criteria were: Negative markers for viral hepatitis $\mathrm{B}$ and $\mathrm{C}$ infections, autoimmune hepatitis, patients who used hepatotoxic drugs, history of alcohol intake, primary biliary cirrhosis, hepatocellular carcinoma, liver cirrhosis or decompensated liver disease, patients on parenteral nutrition, coronary heart disease, diabetic nephropathy or metabolic liver disease (as hemochromatosis and Wilson disease).

One hundred thirty eight of apparently healthy blood volunteers of matched age and sex to patients were enrolled in the study as a control group. They have normal liver enzymes, negative for viral hepatitis $\mathrm{B}$ and $\mathrm{C}$, and normal liver ultrasonography.
All patients and controls were subjected to complete medical and anthropometric examination. Body mass index (BMI) was calculated as weight (in kilograms) divided by height squared (meters squared). Waist circumference (at the nearest half centimetre) was measured at the midpoint between the lower rib margin and the iliac crest.

The following investigations were done to all participates:

After an overnight fasting, venous blood was withdrawn in the morning from all fasting participates included in the study and put in plain vacutianer tubes, separated serum was used for measuring glucose, insulin and lipid profile (triglycerides, total cholesterol and HDL cholesterol, then LDL cholesterol was calculated). Also, serum samples were used for immediate assay of liver function tests (ALT, AST, Albumin, GGT and ALP), all biochemical tests were done by using the Integra 800 Auto analyzer (Roche-Germany).

The fasting insulin level was determined by an enzyme linked immunosorbent assay (ELISA) technique, the kit provided by Diagnostic System Laboratories incorporation (DSL-10-1600 ACTIVE insulin, Texas-USA). Sample, controls and standards were incubated with first HRP labeled antiinsulin antibody in microwells coated with another anti-insulin antibody, the assay steps was performed according to the manufacturer's instructions. The minimum detection limit is $0.26 \mathrm{uIU} / \mathrm{ml}$, the intraand inter-assay coefficient variations were $2.6 \%$ and $6.2 \%$ respectively. The degree of insulin resistance was calculated from the homeostasis model assessment (HOMA) and the HOMA index $>3$ is a criterion of insulin resistance. The HOMA-IR was calculated by the formula [12]:

$$
\begin{gathered}
\text { Fasting plasma insulin (micro-international units /ml) x } \\
\text { Fasting plasma glucose (millimoles / liter) } \\
22.5
\end{gathered}
$$

The detection of serum ACE was done using an Enzyme Immunoassay for the detection of ACE Kit from Chemicon international Cat. No. ACE100 (USA). The method measures ACE based on immunoreactivity rather than enzyme activity. Monoclonal mouse antibodies generated against human $\mathrm{ACE}$ are coated onto a microplate well, and are used to capture ACE present in a sample. ACEspecific and the peroxidase-conjugated, sheep polyclonal antibodies detect the captured ACE. The amount of ACE is determined from a standard curve after the addition of the substrate and stop solution. The absorbance is directly proportional to ACE concentration and the higher absorbance is the higher the ACE concentration in the sample. 
Sensitivity: $>12 \mathrm{ng} / \mathrm{mL}$, the range of detection: 15.6 to $800 \mathrm{ng} / \mathrm{mL}$, intra-assay variation: $5 \%$ and interassay variation: $5 \%$

TGF- $\beta 1$ was measured by using an ELISA method from (R\&D) it is a quantitative sandwich enzyme immunoassay technique. The microplate has been pre-coated by a monoclonal antibody specific for TGF- $\beta 1$, the samples, standards and controls are pipetted into wells and TGF- $\beta 1$ present in the sample is bound by the antibody coated in these wells. The washing was done to away any unbound substances, and then an enzyme-linked polyclonal antibody specific for TGF- $\beta 1$ is added to the wells. After that, substrate solution is added to the wells and color develops in the well is proportion to the amount of TGF- $\beta 1$ present in the sample. The color development is stopped by addition of diluted acid, the intensity of the color is measured by an ELISA plate reader.

Genotyping of ACE was done; the genomic DNA was extracted from EDTA peripheral blood samples using QIAamp DNA Mini Kit for DNA extraction (Qiagen, Tokyo, Japan). Polymerase chain reaction (PCR) was performed to detect ACE gene polymorphism according to by Rigat et al (1992) method. The primers used for PCR were: sense 5' CTG GAG ACC ACT CCC ATC CTT TCT 3' (sense) and antisense 5' GAT GTG GCC ATC ACA TTC GTC AGA 3' (antisense). Three $\mathrm{mmol} / \mathrm{L}$ of $\mathrm{MgCl} 2,50 \mathrm{mmol} / \mathrm{L}$ of $\mathrm{KCl}, 10$ of $\mathrm{mmol} / \mathrm{L}$ Tris- $\mathrm{HCl}$ of $\mathrm{pH} 8.4,0.1 \mathrm{mg} / \mathrm{ml}$ gelatin, $0.5 \mathrm{mmol} / \mathrm{L}$ of each dNTP and $1 \mathrm{U}$ of Taq polymerase were put in microtube in a final volume of 50ul. The cycle protocol for DNA amplification was: 30 cycles with denaturation at $94^{\circ} \mathrm{C}$ for $1 \mathrm{~min}$, annealing at $58^{\circ} \mathrm{C}$ for $1 \mathrm{~min}$, and extension at $72^{\circ} \mathrm{C}$ for $2 \mathrm{~min}$. After that PCR 5 bothe resulting PCR products were applied to $1.5 \%$ agarose gel electrophoresis and then visualized by ethidium bromide staining. Allele identification (I or D) and genotyped was done for each sample according to the PCR product sizes. The ACE gene polymorphism was determined as a 190-base pair fragment in the absence of insertion (D allele), and as a 490-base pair in the presence of insertion (I allele). Therefore, each DNA sample revealed one of three possible patterns: A 190-base pair band (genotype DD), 490-base pair band (genotype II), or both 490-base pair and 190-base pair bands (genotype I/D).

\section{Statistics:}

The data were statistically analysed using with SPSS 21.0 (SPSS, Inc., Chicago, IL). Data were expressed as mean \pm SD and differences between groups are analysed by student $(t)$ test, Mann-
Whitney or ANOVA tests. Chi square or Fisher's exact test are used to compare categorized variables. Differences considered to be significant when $p$ value $<0.05$.

\section{Results}

The study included 162 patients of NAFLD disease, 97 males and 65 females, their mean age is $41.3 \pm 7.6$ years. Diabetes mellitus was detected in $42(25.93 \%)$ patients and $52(32.09 \%)$ of NAFLD patients were hypertensive. The fibrosis stage was assessed in the NAFLD patients, whereas 49 $(30.25 \%)$ have mild fibrosis and $65(40.12 \%)$ have moderate fibrosis and 48 (29.63\%) patients have severe fibrosis and cirrhosis (Table 1).

Table (1): Demographic data of NAFLD patients and controls.

\begin{tabular}{|c|c|c|}
\hline Parameters & $\begin{array}{l}\text { NAFLD group } \\
\qquad \begin{array}{c}(\mathrm{n}=162) \\
\mathrm{M} \pm \mathrm{SD}\end{array}\end{array}$ & $\begin{array}{c}\text { Control group } \\
(\mathrm{n}=138) \\
\mathrm{M} \pm \mathrm{SD}\end{array}$ \\
\hline Gender (male/female) & $97 / 65$ & $87 / 51$ \\
\hline Age (years) & $41.3 \pm 7.6$ & $39.4 \pm 8.5$ \\
\hline Body weight (kg) & $87.2 \pm 10.2$ & $74.6 \pm 6.1$ \\
\hline Height (m) & $166.4 \pm 8.9$ & $170.2 \pm 7.8$ \\
\hline Waist circumference $(\mathrm{cm})$ & $96.4 \pm 8.6$ & $85.5 \pm 7.4$ \\
\hline BMI $\left(\mathrm{kg} / \mathrm{m}^{2}\right)$ & $29.5 \pm 5.7$ & $25.1 \pm 2.3$ \\
\hline Diabetes mellitus (no \%) & $42(25.93 \%)$ & 0 \\
\hline Hypertension (no \%) & $52(32.09 \%)$ & 0 \\
\hline \multicolumn{3}{|l|}{ Fibrosis stage: } \\
\hline Mild fibrosis (stage 1-2) & $49(30.25 \%)$ & \\
\hline Moderate fibrosis (stage $3-4$ ) & $65(40.12 \%)$ & \\
\hline Severe fibrosis (stage 5-6) & $48(29.63 \%)$ & \\
\hline
\end{tabular}

The comparison between NAFLD patients and controls revealed that, the fasting glucose, fasting insulin, HOMA-IR, AST, ALT and GGT were significantly increased in NAFLD patients more than controls $(p<0.05$ for each and $p<0.01$ for GGT). While triglycerides, total cholesterol and total bilirubin were not significantly different between NAFLD patients and controls (Table 2).

Table (2): Comparison between biochemical parameters of NAFLD patients and controls.

\begin{tabular}{llll}
\hline Parameters & $\begin{array}{c}\text { NAFLD group } \\
(\mathrm{n}=162) \\
\mathrm{M} \pm \mathrm{SD}\end{array}$ & $\begin{array}{c}\text { Control group } \\
(\mathrm{n}=138) \\
\mathrm{M} \pm \mathrm{SD}\end{array}$ & $\begin{array}{c}p \text { - } \\
\text { value }\end{array}$ \\
\hline Fasting glucose $(\mathrm{mg} / \mathrm{dl})$ & $94.6 \pm 10.2$ & $82.3 \pm 9.22$ & $<0.05$ \\
Fasting insulin $(\mathrm{uIU} / \mathrm{ml})$ & $10.8 \pm 3.51$ & $6.11 \pm 2.73$ & $<0.05$ \\
HOMA-IR & $3.47 \pm 1.92$ & $2.53 \pm 1.64$ & $<0.05$ \\
Triglycerides $(\mathrm{mg} / \mathrm{dl})$ & $171.4 \pm 25.6$ & $152.42 \pm 16.2$ & $>0.05$ \\
T. cholesterol $(\mathrm{mg} / \mathrm{dl})$ & $196.52 \pm 30.4$ & $1.32 \pm 0.74$ & $>0.05$ \\
T. bilirubin $(\mathrm{mg} / \mathrm{dl})$ & $1.63 \pm 0.61$ & $23.5 \pm 9.8$ & $>0.05$ \\
AST $(\mathrm{IU} / \mathrm{L})$ & $46.5 \pm 23.7$ & $28.5 \pm 5.4$ & $<0.05$ \\
ALT $(\mathrm{IU} / \mathrm{L})$ & $51.4 \pm 26.1$ & $42.1 \pm 7.9$ & $<0.05$ \\
GGT $(\mathrm{IU} / \mathrm{L})$ & $69.3 \pm 5.4$ & & $<0.01$ \\
\hline
\end{tabular}

$p$-value significant if $<0.05$. 
Regarding the ACE gene frequency, no significant differences was detected in the frequency of homozygous $\mathrm{I} / \mathrm{I}$ and D/D or D/I polymorphism between NAFLD patients and controls. Moreover, the ACE allele's frequency of insertion and deletion (I and D) showed no significant difference. The serum ACE and TGF-b were significantly increased $(p<0.05$ and $p<0.01$ respectively) in NAFLD patients compared to controls (Table 3 ).

Table (3): Frequency of ACE genotypes, serum ACE and TGF-b in NAFLD patients versus health control group.

\begin{tabular}{lccc}
\hline Parameters & $\begin{array}{c}\text { NAFLD patients } \\
(\mathrm{n}=162)\end{array}$ & $\begin{array}{c}\text { Control group } \\
(\mathrm{n}=138)\end{array}$ & $\begin{array}{c}p- \\
\text { value }\end{array}$ \\
\hline $\begin{array}{c}\text { ACE genotypes: } \\
\text { I/I (n \%) }\end{array}$ & $28(17.28 \%)$ & $26(18.84 \%)$ & $>0.05$ \\
D/I (n \%) & $74(45.69 \%)$ & $82(59.42 \%)$ & \\
D/D (n \%) & $60(37.03 \%)$ & $30(21.74 \%)$ & \\
ACE alleles: & & & \\
I (n \%) & $130(40.12 \%)$ & $134(48.55 \%)$ & $>0.05$ \\
D (n \%) & $194(59.88 \%)$ & $142(51.45 \%)$ & \\
$\begin{array}{c}\text { Serum ACE }(\mathrm{ng} / \mathrm{ml}): \\
\mathrm{M} \pm \mathrm{SD}\end{array}$ & $18.3 \pm 3.29$ & $10.6 \pm 2.05$ & $<0.05$ \\
$\begin{array}{c}\text { TGF } b(\mathrm{ng} / \mathrm{ml}): \\
\mathrm{M} \pm \mathrm{SD}\end{array}$ & $55.41 \pm 9.32$ & $36.25 \pm 11.41$ & $<0.01$ \\
\hline
\end{tabular}

The comparison between ACE genotypes regarding the patients demographic and biochemical data showed that, a HOMA-IR, ALT, serum ACE and TGF-b were significantly higher in the patients carrying D/D homozygous gene than carrying homozygous I/I or D/I polymorphism (Table 4).

Table (4): Comparison between ACE genotypes among NAFLD patients regarding the biochemical tests.

\begin{tabular}{lllll}
\hline Parameters & $\begin{array}{c}\mathrm{I} / \mathrm{I} \\
(\mathrm{n}=28) \\
\mathrm{M} \pm \mathrm{SD}\end{array}$ & $\begin{array}{c}\mathrm{D} / \mathrm{I} \\
(\mathrm{n}=74) \\
\mathrm{M} \pm \mathrm{SD}\end{array}$ & $\begin{array}{c}\mathrm{D} / \mathrm{D} \\
(\mathrm{n}=60) \\
\mathrm{M} \pm \mathrm{SD}\end{array}$ & $\begin{array}{c}p \text { - } \\
\text { value }\end{array}$ \\
\hline BMI & $27.2 \pm 2.6$ & $28.3 \pm 3.5$ & $30.2 \pm 4.8$ & $>0.05$ \\
HOMA-IR & $2.72 \pm 1.12$ & $3.44 \pm 0.9$ & $4.46 \pm 1.2$ & $<0.05$ \\
ALT (IU/L) & $45.3 \pm 16.2$ & $54.9 \pm 9.5$ & $62.2 \pm 11.6$ & $<0.05$ \\
Fasting glucose & $86.4 \pm 4.3$ & $91.8 \pm 6.1$ & $97.2 \pm 8.5$ & $>0.05$ \\
$\quad(\mathrm{mg} / \mathrm{dl})$ & & & & \\
TGF-b (ng/ml) & $48.2 \pm 7.31$ & $59.62 \pm 8.64$ & $62.84 \pm 4.65$ & $<0.05$ \\
ACE (ng/ml) & $16.41 \pm 3.11$ & $17.12 \pm 1.88$ & $20.54 \pm 1.07$ & $<0.05$ \\
\hline
\end{tabular}

The frequency of homozygous D/D genotype was significantly associated with cases with severe liver fibrosis and homozygous I/I genotype was associated with mild fibrosis. Also, the D allele was more frequent in cases with severe fibrosis while the I allele was considered as a protective allele from advanced fibrosis. The serum levels of $\mathrm{ACE}$ and TGF-b were significantly increased in the patients with severe fibrosis compared to moderate and mild fibrosis (Table 5 and Fig. 1).
Table (5): Comparison between ACE genotypes in NAFLD patients regarding the stage of liver fibrosis.

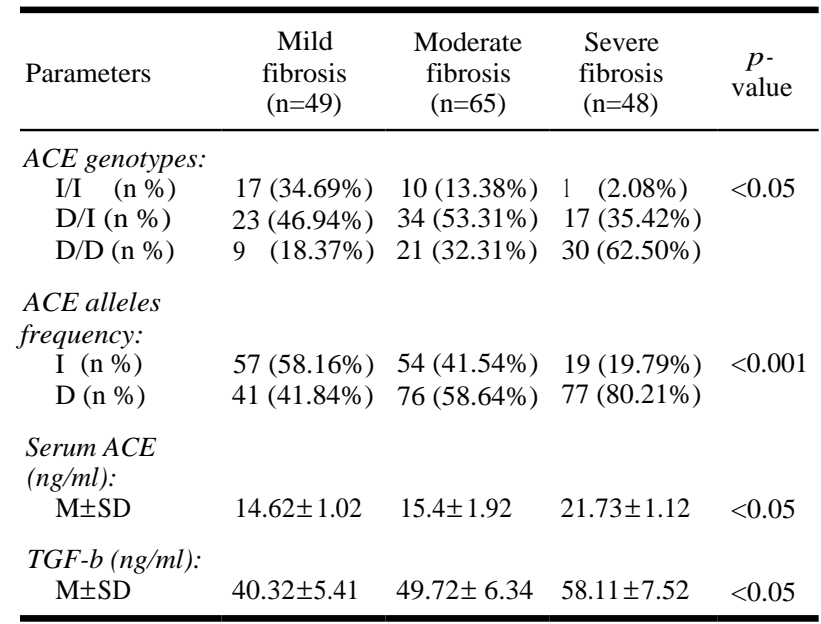

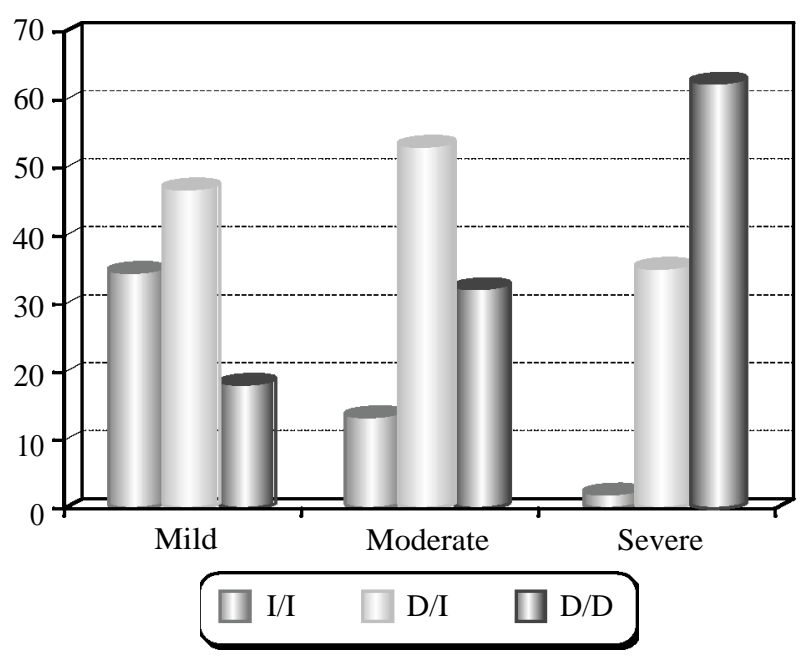

Fig. (1): Shows the frequency of ACE genotypes in NAFLD patients regarding the stage of liver fibrosis.

\section{Discussion}

Angiotensin-converting enzyme (ACE) polymorphism, resulting from the insertion (I) or deletion (D) of a 287-base pair sequence in intron 16, may influence the expression level and activity of ACE [13]. This study was designed to identify the relationship between ACE gene polymorphism and development of steatohepatitis in patients with NAFLD.

The study included 162 patients of NAFLD disease and 138 of healthy volunteer subjects. The stage of liver fibrosis was mild in 49/162 (30.25\%) among NAFLD patients, whereas 65/162 (40.12\%) have moderate fibrosis and 48/162 (29.63\%) patients have severe fibrosis and cirrhosis. Serum glucose, insulin, HOMA-IR, AST, ALT and GGT were significantly higher in NAFLD patients compared to health controls. The serum triglycerides, total cholesterol and total bilirubin were not sig- 
nificantly different among NAFLD patients and controls. These findings are agreed with Yoon et al. [14], who reported that NAFLD is associated with increased serum insulin level and IR even in non-obese subjects, suggesting IR is considered the most pathognomonic risk factor responsible for NAFLD development. On the other hand, Hui et al. [15], stated insulin has ability to generate oxidative stress or up-regulation of the lipidsprotein, sterol regulatory element-binding protein, which may cause direct and indirect liver cell injury especially in hyperglycemia state. The liberation and up-regulation of these toxic substances seem to have direct profibrogenic effects by stimulating connective tissue growth factor, especially in cases with hyperglycemia [16]

The current study revealed, no significant difference was detected in the frequency of homozygous $\mathrm{I} / \mathrm{I}$ and $\mathrm{D} / \mathrm{D}$ or $\mathrm{D} / \mathrm{I}$ polymorphism or ACE allele's frequency (I or D) between NAFLD patients and healthy controls. An interesting finding was found in this study, the patients harboring homozygous D/D gene showed a significant increase of HOMA-IR, ALT, serum ACE and TGF$\mathrm{b}$ than those patients carrying homozygous I/I or D/I polymorphism, suggesting the associated D/D genotype with risk factor of NAFLD development. Many previous studies suggested that, the carriage of D allele may favor the development of atherosclerosis through the influence exerted on other atherogenic factors such as hyperglycaemia, hyperlipidaemia, and high BMI [17]. Bataller et al. [18] found that serum ACE levels were increased in individuals harbor D/D allele of ACE gene in patients with diabetic nephropathy.

Güçlü et al. [8], reported that the high frequency of D/D genotype of ACE was associated with IR, systemic hypertension, diabetes and coronary heart disease simillarly in NAFLD/NASH group, as a reflection of metabolic syndrome. Additionally, the ACE polymorphisms might be one of the genetic factors influencing the course of chronic hepatitis $\mathrm{C}$ (CHC) [4], which is modulated by metabolic factors such as IR and obesity. In another study carried on liver transplant patients, the weight gain in the first year later after transplantation is more associated to the ACE polymorphism and is highest in those harboring the D/D genotype, while lowest in those carrying the I/I genotype [19]. In another study by Fabris et al. [20] they reported that, the carriage of the ACE I/I genotype was associated with the women of lower BMI.

Multiple gene polymorphisms were associated with different degrees of liver fibrosis, among them, ACE gene I/D polymorphism has been one of the most investigated gene [21]. In this study, ACE gene (I/D) polymorphism was associated with moderate fibrosis (stage 2-3). While, the frequency of homozygous D/D genotype was more associated with severe liver fibrosis and homozygous I/I genotype was associated with mild degree of fibrosis. Moreover, the D allele was frequently higher in cases with severe liver fibrosis, than I allele, suggesting that, I allele may be considered a protective allele from development of advanced fibrosis. Therefore the suppression of RAS may be an inevitable strategy for preventing liver fibrosis progression. Paizis et al. [22] reported that ACE gene was up-regulated in induced liver fibrosis in experimental mice. Warner et al. [4] suggested that up-regulation of hepatic ACE is accelerated during fibrogenesis and is included in the developed liver fibrosis. Also, Efe et al. [23] suggested that ACE sustains hepatic fibrogenesis in autoimmune hepatitis (AIH) and the serum levels of ACE is increased and associated with each fibrosis score.

Several studies, reported that, the angiotensin receptor blockers or ACE inhibitors have been shown to ameliorate the liver fibrosis progression, Jonsson et al. [24] and Zhu et al. [6] suggesting that ACE gene expression may be an important marker for liver fibrosis severity. Turhan et al. [25], reported that, the frequency of I/D genotypes were higher than the D/D and I/I genotypes both mild to moderate and advanced fibrosis, these findings were partially agreed with our findings. Additionally, Güçlü et al. [8], reported that, no significant relation between $\mathrm{D} / \mathrm{D}, \mathrm{D} / \mathrm{I}$ and $\mathrm{I} / \mathrm{I}$ genotype frequency and liver fibrosis. They found also, a positive association between the increase in the frequency of $D$ allele and liver steatosis, while a negative relationship was observed with a low frequency of I allele, these findings were in agreement with our results.

On the contrary, Forrest et al. [26], Fabris et al. [20] and Raslan et al. [27], suggested that no relation was observed between ACE (I/D) gene polymorphism and fibrosis development in patients with CHC. Fabris et al. [20] also reported that, ACE (I/I) homozygote patients had higher liver fibrosis scores than ACE (D/D) homozygote and ACE (I/D) heterozygote patients.

Also Amal et al. [28] study, reported no significant relation between ACE polymorphism and degree of liver fibrosis in patients with CHC. These controversies could be attributed to the different aetiology of liver fibrosis and/or to different stage of fibrosis severity suggested by these studies. 
Tekatas et al. [29], found no significant association between degree of liver fibrosis and ACE genotypes in NAFLD subgroups. This discrepancy explained by the pathological risk of ACE (D/D) genotype varies between populations with different genetic and environmental backgrounds.

Many reports have validated whether the serum ACE and TGF-b serum level has the clinical potential to predict liver fibrosis. In the current study, serum levels of ACE and TGF-b were significantly increased in NAFLD patients compared to controls, and the higher level was in patients with severe liver fibrosis than moderate and mild fibrosis. In agreement with our results, Noguchi et al. [30] and Wu et al. [31] they showed that, serum ACE level was increased in cases with liver fibrosis and its level increased gradually with fibrosis progression. Similarly, Tekatas et al. [29] reported that, transforming growth factor 3 (TGF- $\beta$ ) cause a progression of fibrosis by stimulating proliferation of HSC.

In conclusion: From the previous findings, there is a significant association between $\mathrm{ACE}$ homozygous gene (D/D) and severe liver fibrosis, and ACE polymorphism (I/D) was associated with moderate stage of fibrosis. The $\mathrm{D}$ allele may be considered a risk factor for development of liver fibrosis and I was a protective allele. Further large-scale studies into this field and should include comparing RAAS different genes are recommended.

\section{References}

1- BATALLER R. and BRENNER D.A.: Liver fibrosis. Clin. Invest., 115: 209-218, 2005.

2- BROWNING J.D. and HORTON J.D.: Molecular mediators of hepatic steatosis and liver injury. J. Clin. Invest., 114: 147-152, 2004.

3- MARSHALL R.P., McANULTY R.J. and LAURENT G.J.: Angiotensin II is mitogenic for human lung fibroblasts via activation of the type 1 receptor. Am. J. Respir. Crit. Care Med., 161: 1999-2004, 2000.

4- WARNER F.J., LUBEL J.S., McCAUGHAN G.W. and ANGUS P.W.: Liver fibrosis: A balance of ACEs. Clin. Sci. (Lond), 113: 109-118 [PMID: 17600527 DOI: 10.1042/CS20070026], 2007.

5- LIU J., GONG H., ZHANG Z.T. and WANG Y.: Effect of angiotensin II and angiotensin II type 1 receptor antagonist on the proliferation, contraction and collagen synthesis in rat hepatic stellate cells. Chin Med. J., 20; 121 (2): 161-165, 2008.

6- ZHU Q., LI N., LI F., ZHOU Z., HAN Q., LV Y., SANG J. and LIU Z.: Therapeutic effect of renin angiotensin system inhibitors on liver fibrosis. Journal of the ReninAngiotensin Aldosterone System, (1-3): 1-9, 2016.
7- RIGAT B., HUBERT C., CORVOL P. and SOUBRIER F.: PCR detection of the insertion/deletion polymorphism of the human angiotensin converting enzyme gene (DCP1) (dipeptidyl carboxypeptidase 1). Nucleic Acids Res., 20: 1433-1437, 1992.

8- GÜÇLÜ M., YAKAR T. and SERIN E.: Angiotensin Converting Enzyme Gene (I/D) Polymorphism and Nonalcoholic Fatty Liver Disease. Eur. J. Gen Med., 7 (2): 136-142, 2010.

9- CAMBIEN F., POIRIER O., LECERF L., EVANS A., CAMBOU J.P. and ARVEILER D.: Deletion polymorphism in the gene for angiotensin converting enzyme is a potent risk factor for myocardial infarction. Nature, 359: 641-644, 1992.

10- FRANCESCO P., ROBERTO C. and SAVERIO I.: Relationship between angiotensin-converting enzyme gene polymorphism and insulin resistance in never-treated hypertensive patients. J. Clin. Endocrinol. Metab., 86: 172-178, 2001.

11- ISHAK K., BAPTISTA A., BIANCHI L., CALLEA F., et al.: Histological grading and staging of chronic hepatitis. J. Hepatol., 22: 696-699, 1995.

12- EMOTO M., NISHIZAWA Y., MAEKAWA K., HIURA Y., KANDA H., KAWAGISHI T., SHOJI T., OKUNO Y. and MORII H.: Homeostasis model assessment as a clinical index of insulin resistance in type 2 diabetic patients treated with sulfonylureas. Diabetes Care. May, 22 (5): 818-822, 1999.

13- ORUC N., LAMB J., WHITCOMB D.J. and SASS D.A.: The ACE gene I/D polymorphism does not affect the susceptibility to or prognosis of PBC. Turk J. Gastroenterol., 19 (4): 250-253, 2008.

14- YOON D., LEE S.H., PARK H.S., LEE J.H., et al.: Hypoadiponectinemia and insulin resistance are associated with nonalcoholic fatty liver disease. J. Korean Med. Sci., 20 (3): 421-426, 2005.

15- HUI J.M., SUD A., FARRELL G.C., BANDARA P., BYTH K., KENCH J.G., McCAUGHAN G.W. and GEORGE J.: Insulin resistance is associated with chronic hepatitis $\mathrm{C}$ virus infection and fibrosis progression. Gastroenterology, 125: 1695-1704, 2003.

16- ARTHUR J. and McCULLOUGH: Pathogenesis of Nonalcoholic Steatohepatitis: Human Data. Open Access Clin. Liver Dis., 11: 75-104, 2007.

17- UEMURA K., NAKURA J., KOHARA K. and MIKI T.: Association of ACE I/D polymorphism with cardiovascular risk factors. Hum Genet, 107: 239-242, 2000.

18- BATALLER R., GINES P., NICOLOS J.M., GORBIG M.N., GARCIA-RAMALLO E. and GASUL X.: Angiotensin II induces contraction and proliferation of human hepatic stellate cels. Gastroenterolgy, 118: 1149-1152, 2000 .

19- TONIUTTO P., FABRIS C., MINISINI R., et al.: Weight gain after liver transplantation and the insertion/deletion polymorphism of the angiotensin-converting enzyme gene. Transplantation, 79: 1338-1343, 2005.

20- FABRIS C., SMIRNE C., FANGAZIO C., TONIUTTO P., BURLONE M., MINISINI M., BITETTO D., FALLETI E., CERUTTI A. and PIRISI M.: Influence of angiotensinconverting enzyme I/D gene polymorphism on clinical 
and histological correlates of chronic hepatitis C. Hepatology Research, 39: 795-804. DOI: 10.1111/j.1872034X.2009.00518, 2009.

21- SCHUPPAN D., KREBS A., BAUER M., HAHN E.G. Hepatitis c and liver fibrosis. Cell Death Differ., 10 (Suppl 1): S59-S67, 2003

22- PAIZIS G., COOPER M.E., SCHEMBRI J.M., TIKELLIS C., BURRELL L.M. and ANGUS P.W.: Up-regulation of components of the renin-angiotensin system in the bile duct-ligated rat liver. Gastroenterology, 123: 1667-1676 [PMID: 12404241], 2002.

23- EFE C., CENGIZ M., KAHRAMANOG LU-AK^OY E., YILMAZ B., ÖZSEKER B, BEYAZT Y., TANOGLU A., PURNAK T., KAV T., TURHAN T., OZENIRLER S., OZASLAN E., WAHLIN S.: Angiotensin-converting enzyme for non invasive assessment of liver fibrosis in autoimmune hepatitis. Eur. J. Gastroenterol Hepatol., 27: 649-654 [PMID: 25860719. DOI: 10.1097/MEG.00000 00000000355], 2015.

24- JONSSON J.R., CLOUSTON A.D., ANDO Y., KELEMEN L.I., HORN M.J., ADAMSON M.D., PURDIE D.M. and POWELL E.E.: Angiotensin-converting enzyme inhibition attenuates the progression of rat hepatic fibrosis. Gastroenterology. Jul., 121 (1): 148-55, 2001.

25- TURHAN N.K., ILIKHAN S.U., HAMAMCIOGLU A.C., Y. USTUNDAG Y., DURSUN A. and KOKTURK K.: Angiotensin-converting enzyme gene polymorphism (insertion/deletion) and liver fibrosis in Turkish patients from the western Black Sea region, Turkey. Genetics and Molecular Research, 14 (4): 17079-17090, 2015.

26- FORREST E.H., THORBURN D., SPENCE E., OIEN
K.A., et al.: Polymorphisms of the renin-angiotensin system and the severity of fibrosis in chronic hepatitis $\mathrm{C}$ virus infection. J. Viral. Hepat., 12: 519-524, 2005.

27- RASLAN H.M., AMR K.S., ELHOSARY Y.A., EZZAT W.M., et al.: Possible role of angiotensin-converting enzyme polymorphism on progression of hepatic fibrosis in chronic hepatitis $\mathrm{C}$ virus infection. Trans. R. Soc. Trop. Med. Hyg., 105: 396-400, 2011.

28- AMAL M.H. MACKAWY, MOHAMMED E.H. BADAWY and OLA ABD EL-RAHMAN YOSSEF MEGAHED: Angiotensin converting enzyme (ACE D/I) polymorphism and its relation to liver fibrosis progression in Egyptian patients with chronic hepatitis $\mathrm{C}$ virus infection. The Egyptian Journal of Medical Human Genetics, 13: 291-299, 2012.

29- TEKATAS D.D., BAHCECIOGLU I.H., ISPIROGLU M., SAHIN A., ILHAN N., YALNIZ M. and DEMIREL U.: Role of Renin-Angiotensin-converting Enzyme Level and ACE Gene Polymorphism in Patients with Nonalcoholic Fatty Liver Disease. Euroasian J. HepatoGastroenterol., 6 (2): 137-142, 2016.

30- NOGUCHI R., KAJI K., NAMISAKI T., MORIYA K., KITADE M., TAKEDA K., KAWARATANI H., OKURA Y., AIHARA Y., FURUKAWA M., MITORO A. and YOSHIJI H.: Serum angiotensin-converting enzyme level for evaluating significant fibrosis in chronic hepatitis B. World J. Gastroenterol., 28; 23 (36): 6705-6714. DOI: 10.3748/wjg.v23.i36.6705, 2017.

31- WU H., CHUANG Y., HUANG C. and CHANG M.: Loss of angiotensin converting enzyme II (ACE2) accelerates the development of liver injury induced by thioacetamide. Exp. Anim., 67 (1): 41-49, 2018.

\section{علاقة التنوع الجينى للأنزيه المحول للأنجيوتنسين-1 (ACE) بحدوث تليف الكبد فى الإلتهاب الكبدى الدهول لأنيونى غير الكين الكحولى}

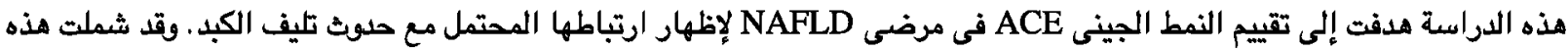

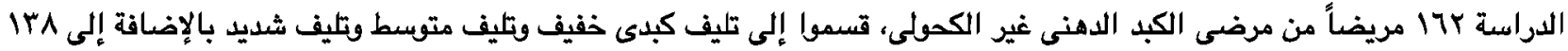

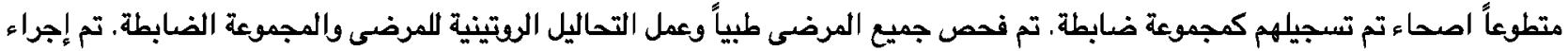

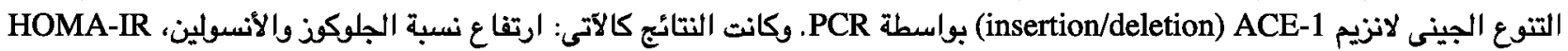

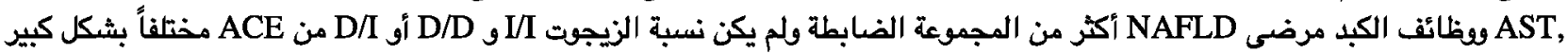
بين مرضى NAFLD المجموعة الضابطة. وقد ارتبط النمط الوراثى D/D بشكل كبير مع شدة تليف الكبد، والنمط D/I مع مع التليف المتوبسط

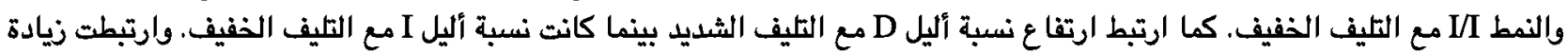
نسبة ACE و ALT و ACE-IR و TGF-b الدم بثكل كبير فى المرضى الذين يحملون جين D/D أكثر من أولئك الذين يحملون جين D/I I/I

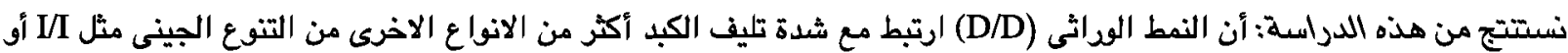

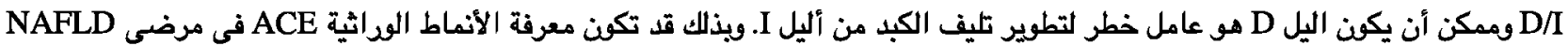

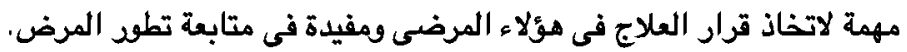

